\title{
Growth Stage Affects Dose Response of Selected Glyphosate-Resistant Weeds to Premix of 2,4-D Choline and Glyphosate (Enlist Duo ${ }^{\text {TM }}$ Herbicide*) $^{*}$
}

\author{
Parminder S. Chahal ${ }^{1}$, Jatinder S. Aulakh ${ }^{1}$, Kristin Rosenbaum ${ }^{2} \&$ Amit J. Jhala ${ }^{1}$ \\ ${ }^{1}$ Department of Agronomy and Horticulture, University of Nebraska-Lincoln, Lincoln, Nebraska, USA \\ ${ }^{2}$ Dow AgroSciences, Crete, Nebraska, USA \\ Correspondence: Amit J. Jhala, Department of Agronomy and Horticulture, University of Nebraska-Lincoln, \\ Lincoln, Nebrask 68583-0915, USA. Tel: 1-402-472-1534. E-mail: Amit.Jhala@unl.edu
}

Received: June 17, 2015 Accepted: August 14, 2015 Online Published: October 15, 2015

doi:10.5539/jas.v7n11p1 URL: http://dx.doi.org/10.5539/jas.v7n11p1

\begin{abstract}
With the intent to control glyphosate-resistant and hard to control weeds, a formulation of 2,4-D choline (24.4\%) and glyphosate (22.1\%) (Enlist Duo ${ }^{\mathrm{TM}}$ herbicide) (Note 1) has been developed recently to be used post-emergence in corn and soybean tolerant to Enlist Duo ${ }^{\mathrm{TM}}$ in the United States. Dose response studies were conducted under greenhouse conditions for the evaluation of effective rates of Enlist Duo ${ }^{\mathrm{TM}}$ to control glyphosate-resistant common waterhemp (Amaranths rudis Sauer), giant ragweed (Ambrosia trifida L.), and kochia [Kochia scoparia $(\mathrm{L}$.) Schrad] and to determine the effect of growth stage of these weeds on the efficacy of Enlist Duo ${ }^{\mathrm{TM}}$. Three parameter log-logistic models were used to develop dose response curves. Glyphosate-resistant giant ragweed was the most sensitive of the three weed species, followed by common waterhemp, and kochia. Based on the visual control or injury estimates, the Enlist Duo ${ }^{\mathrm{TM}}$ rates required for $90 \%$ control $\left(\mathrm{ED}_{90}\right)$ of common waterhemp, giant ragweed, and kochia were 1179,825 , and 4,382 $\mathrm{g}$ ae ha ${ }^{-1}$, respectively, for $10-\mathrm{cm}$ tall plants compared to $2,480,1,101$, and $5,305 \mathrm{~g}$ ae ha $^{-1}$, respectively, for $20-\mathrm{cm}$ tall plants at 21 days after treatment (DAT). The $\mathrm{ED}_{90}$ values calculated on the basis of percent shoot biomass reduction and visual control or injury estimates were usually similar at 21 DAT. The greenhouse studies indicate that Enlist Duo ${ }^{\mathrm{TM}}$ can effectively control less than or equal to $20-\mathrm{cm}$ tall glyphosate-resistant giant ragweed and less than or equal to $10-\mathrm{cm}$ tall glyphosate-resistant common waterhemp at the recommended rate $(1,640 \mathrm{~g}$ ae $\left.\mathrm{ha}^{-1}\right)$.
\end{abstract}

Keywords: broadleaf weeds, Enlist Duo ${ }^{\mathrm{TM}}$, resistance management, weed growth stage, 2,4-D choline and glyphosate

*TM Trademark of the Dow Chemical Company ("Dow") or an affiliated company of Dow.

\section{Introduction}

Simplified and economical weed management programs based on continuous and sole reliance on a single herbicide or herbicide(s) with the same mode(s) of action have resulted in the evolution of herbicide-resistant weeds (Beckie, 2011; VanGessel, 2001). The widespread cultivation of glyphosate-resistant crops since their introduction and commercialization in 1990's and an almost exclusive reliance on glyphosate for POST weed control has raised issues of glyphosate-resistant weeds (Culpepper et al., 2006; Powles et al., 1998; VanGessel, 2001). As of 2014, 34 weed species have been confirmed resistant to glyphosate worldwide (Heap, 2015). Six weed species, including common ragweed (Ambrosia artemisiifolia L.), common waterhemp (Amaranths rudis Sauer), giant ragweed (Ambrosia trifida L.), horseweed [Conyza canadensis (L.) Cronq.], kochia [Kochia scoparia (L.) Schrad], and Palmer amaranth [Amaranthus palmeri S. Wats.] have been confirmed resistant to glyphosate in Nebraska, USA (Jhala, 2015).

Management of glyphosate-resistant weeds is the most significant predicament for growers (Culpepper et al., 2008; Johnson et al., 2009; Norsworthy et al., 2008; Price et al., 2011, 2012). Several weed management strategies have been recommended for controlling glyphosate-resistant weeds, including the use of tillage, cover crops, crop rotation, residual PRE herbicides, tank-mixing glyphosate with other modes of action herbicides, herbicide rotation or use of herbicides with different modes of action, and planting cultivars or crops resistant to 
herbicides other than glyphosate (Aulakh et al., 2011, 2012; Beckie, 2006; Norsworthy et al., 2012; Wilson et al., 2007). In the southeastern United States, growers experiencing problems with glyphosate-resistant weeds, have adopted alternative herbicides, hand weeding, and tillage which, however lead to higher production costs, loss of valuable topsoil, and decline in the area under no-till production systems (Aulakh et al., 2012, 2013; Price et al., 2011; Sosnoskie \& Culpepper, 2014). Nevertheless, there is also a pressing need for novel herbicide-resistant technologies in addition with other weed management strategies to control glyphosate-resistant weeds.

Multiple herbicide-tolerant corn and soybean cultivars have been developed using molecular techniques for addressing the growing needs to control glyphosate-resistant weeds (Green et al., 2008). It includes corn and soybean tolerant to 2,4-D choline $\left(\mathrm{C}_{13} \mathrm{H}_{19} \mathrm{Cl}_{2} \mathrm{NO}_{4}\right)$ along with glyphosate $\left(\mathrm{C}_{8} \mathrm{H}_{6} \mathrm{Cl}_{2} \mathrm{O}_{3}\right)$, also known as the Enlist $^{\mathrm{TM}}$ weed management system (Craigmyle et al., 2013a). Newly developed 2,4-D choline is a low-volatile form of 2,4-D manufactured using Colex-D ${ }^{\mathrm{TM}}$ technology. The spectrum of weed control will be similar to glyphosate and 2,4-D, but will further provide flexibility for applying up to V8 or 76-cm tall corn and up to R2 or full flower stage of soybean. The new herbicide formulation (Enlist Duo ${ }^{\mathrm{TM}}$ herbicide) recently received an approval by the United States Environmental Protection Agency (USEPA).

Enlist Duo ${ }^{\mathrm{TM}}$ will provide an additional tool for the management of glyphosate-resistant and hard-to-control weeds in corn and soybean. Recommended application rate of Enlist Duo will be $1640 \mathrm{~g}$ ae/ha to $2185 \mathrm{~g}$ ae/ha based on the weed growth stage. Understanding of the most effective application rate with respect to weed growth stage is needed to incorporate this new herbicide formulation in POST herbicide programs for controlling glyphosate-resistant weeds in corn and soybean. Preliminary experiments conducted in Nebraska provided $99 \%$ control of glyphosate-resistant giant ragweed when 1,065 $\mathrm{g}$ ae/ha of 2,4-D choline was applied POST in Enlist soybean (unpublished data). The recommended rate of Enlist Duo ${ }^{\mathrm{TM}}$ herbicide applied in this experiment $(1,640$ $\mathrm{g}$ ae/ha) contains 800 and $840 \mathrm{~g}$ of 2,4-D choline and glyphosate, respectively. It is expected that this formulation will be equally effective for controlling other glyphosate-resistant broadleaf weeds. However, scientific literature is not yet available about the response of economically important glyphosate-resistant broadleaf weeds to this formulation. The objectives of this study were to (1) describe the dose-response relationship of Enlist Duo ${ }^{\mathrm{TM}}$ applied POST for controlling glyphosate-resistant weed species including common waterhemp, giant ragweed, and kochia, and (2) determine the effect of growth stage of weed species on dose response of Enlist Duo ${ }^{\mathrm{TM}}$. We hypothesized that Enlist Duo ${ }^{\mathrm{TM}}$ will be effective at least for controlling glyphosate-resistant weeds when applied to $10-\mathrm{cm}$ tall plants at a recommended rate, but a higher rate may or may not be required to control $20-\mathrm{cm}$ tall plants depending on the weed species.

\section{Methods}

\subsection{Plant Material}

Greenhouse studies were conducted at the University of Nebraska-Lincoln to determine the dose response of glyphosate-resistant weeds, including common waterhemp, giant ragweed, and kochia to Enlist Duo ${ }^{\mathrm{TM}}$ applied POST at two growth stages. The seeds of common waterhemp, giant ragweed, and kochia were collected from three different sites with confirmed glyphosate-resistance in Nebraska in last five years. When screened with glyphosate at $1,680 \mathrm{~g}$ ae $\mathrm{ha}^{-1}$ ( $2 \times$ rate) before conducting this study, the survival frequency of these three glyphosate-resistant weeds exceeded $90 \%$. Weed seeds were sown in $28 \times 54 \times 6 \mathrm{~cm}$ germination trays containing potting mix (Berger BM1 potting mix, Berger Peat Moss Ltd, Quebec, Canada). Seedlings at the cotyledon to first true-leaf stage were transplanted in 10-cm-diam plastic pots containing a 3:1 mixture of potting mix and soil. Plants were supplied with adequate nutrients and water, and kept in greenhouse at $30 / 20{ }^{\circ} \mathrm{C}$ day/night temperature and 16-h photoperiod.

\subsection{Herbicide Treatments}

Herbicide treatments included 8 rates $(0,0.25 \times, 0.50 \times, 0.75 \times, 1.0 \times, 1.5 \times, 2.0 \times$, and $2.5 \times)$, where, $1 \times=$ recommended field rate of the formulation of 2,4-D choline and glyphosate $\left(1,640 \mathrm{~g}\right.$ ae ha $\left.{ }^{-1}\right)$. Selected glyphosate-resistant weeds were treated when they were 10 -and $20-\mathrm{cm}$ tall. The recommended adjuvant, liquid ammonium sulfate (N-PAK®AMS Liquid, Winfield Solutions, LLC, St. Paul MN 55164) was mixed with each treatment at $2.5 \% \mathrm{v} / \mathrm{v}$. Herbicide treatments were prepared in distilled water and applied using a single-tip chamber sprayer (DeVries Manufacturing Corp, Hollandale MN 56045) fitted with an 8001E nozzle (Teejet, Spraying Systems Co, Wheaton IL 60187) calibrated to deliver $140 \mathrm{~L} \mathrm{ha}^{-1}$ carrier volume at $207 \mathrm{kPa}$. After herbicide treatment, plants were returned to the greenhouse.

Weed control ratings were assessed visually at 7,14, and $21 \mathrm{~d}$ after treatment (DAT) using a scale ranging from $0 \%$ (no control or injury) to $100 \%$ (complete control or plant death). Visual weed control estimates were based on symptoms such as chlorosis, necrosis, stunting, and death of the treated plants or weeds compared with 
nontreated control plants (Ganie et al., 2015; Sarangi et al., 2014). Aboveground shoot biomass of each weed species was harvested at 21 DAT, oven-dried for $96 \mathrm{~h}$ at $65^{\circ} \mathrm{C}$, and the weight was determined.

\subsection{Experimental Design and Statistical Analysis}

Experimental design was a factorial of eight rates of Enlist Duo ${ }^{\mathrm{TM}}$ and two weed growth stages (10- and 20-cm tall). Pots were arranged in a completely randomized design with four replications and the experiment was repeated twice for the consistency of results. A single plant per pot was considered as an experimental unit.

The shoot biomass data were converted into percent shoot biomass reduction compared with the nontreated control (Wortman, 2014):

$$
\text { Percent shoot biomass reduction }=[(\bar{C}-B) / \bar{C}] \times 100
$$

Where, $\bar{C}$ is the mean shoot biomass of the four nontreated control replicates, and $B$ is the shoot biomass of a treated individual experimental unit.

Data were subjected to ANOVA using the PROC GLIMMIX procedure in SAS (SAS version 9.3, SAS Institute Inc, Cary, NC) to test for treatment-by-experiment interaction. Where the ANOVA indicated treatment effects were significant, means were separated at $\mathrm{P} \leq 0.05$ using Fisher's protected LSD test. Visual weed control or injury estimate and shoot biomass reduction (as a percentage compared to the nontreated control) data were regressed over herbicide treatments using the three-parameter log-logistic model (Seefeldt et al., 1995).

$$
\mathrm{Y}=\mathrm{D} / 1+\exp [\mathrm{B}-(\log (\mathrm{X})-\log (\mathrm{E}))]
$$

Where, $\mathrm{Y}$ is the response variables (percent weed control estimates or percent reduction in shoot biomass), $\mathrm{D}$ is the upper limit, $\mathrm{B}$ is the slope of the line, $\mathrm{E}$ is the dose resulting in a $50 \%$ or $90 \%$ control (known as $\mathrm{ED}_{50}$ or $\mathrm{ED}_{90}$ ), and $\mathrm{X}$ is the herbicide rate. Analyses of dose-response curves were performed separately for each weed species and $\mathrm{ED}_{50}$ and $\mathrm{ED}_{90}$ values were determined using the drc package (drc 1.2, Christian Ritz and Jens Strebig, R2.5, Kurt Hornik, online) in software R (R statistical software, R Foundation for Statistical Computing, Vienna, Austria; http://www.R-project.org) (Ritz \& Streibig, 2005). The regression parameters were obtained using the nonlinear least-squares function of the statistical software $\mathrm{R}$ and graphical presentation was generated using the same software. The anova function was used to perform the lack of fit test and the p-value of $\geq 0.05$ indicates the acceptable description of the data by the fitted non-linear model.

\section{Results and Discussion}

Treatment-by-experiment interaction was not significant; therefore, data were pooled over two experiments and combined data are presented. A test of lack of fit at the $95 \%$ level was non-significant for any of the curves tested, indicating fitted models were correct and regression parameters along with $\mathrm{ED}_{50}$ and $\mathrm{ED}_{90}$ values were determined (Tables 1 and 2).

\subsection{Common Waterhemp}

Growth stage of glyphosate-resistant common waterhemp at the time of herbicide application affected control and shoot biomass reduction $(\mathrm{P}<0.0001)$. At the recommended rate $\left(1,640 \mathrm{~g} \mathrm{ae} \mathrm{ha}^{-1}\right)$ of Enlist Duo ${ }^{\mathrm{TM}}$ herbicide, common waterhemp was controlled 90 and $62 \%$ for 10 - and $20-\mathrm{cm}$ tall plants, respectively, at 14 DAT (data not shown). At 21 DAT, common waterhemp control increased to $95 \%$ for $10-\mathrm{cm}$ tall plants compared to $80 \%$ for 20 -cm tall plants (Figure 1A, Table 1). Higher rates $\left(\geq 2,480 \mathrm{~g}_{\text {ae }} \mathrm{ha}^{-1}\right)$ were required to achieve $90 \%$ control of $20-\mathrm{cm}$ tall common waterhemp plants. Several studies have reported that the height of weed species at the time of POST herbicide application is an important factor determining the level of control achieved (Chahal et al., 2014; Cordes et al., 2004; Craigmyle et al., 2013b).

The application rates of Enlist Duo ${ }^{\mathrm{TM}}$ required for 50 and $90 \%$ control of common waterhemp at 21 DAT were 339 and 1,179 $\mathrm{g}_{\text {ae ha }} \mathrm{a}^{-1}$, respectively, for 10-cm tall plants compared to 484 and 2,480 $\mathrm{g}$ ae ha ${ }^{-1}$, respectively, for 20 -cm tall plants (Table 1). Similarly, Robinson et al. (2012) reported poor control $(<50 \%)$ of 20 - to 30 -cm tall common waterhemp with 2,4-D $\left(280 \mathrm{~g}\right.$ ae ha $\left.^{-1}\right)$ and higher rates $\left(1,120 \mathrm{~g} \mathrm{ae} \mathrm{ha}^{-1}\right)$ were required to achieve $>90 \%$ control. Spaunhorst and Bradley (2013) reported 30 to $40 \%$ control of $15-$ to $30-\mathrm{cm}$ tall glyphosate-resistant common waterhemp compared to $62 \%$ control of $7.5-\mathrm{cm}$ tall plants with a tank-mixture of dicamba and glyphosate. The rates required for 50 and $90 \%$ shoot biomass reduction were 303 and $883 \mathrm{~g}$ ae ha ${ }^{-1}$, respectively, for 10-cm tall plants compared to 388 and 2,668 $\mathrm{g}^{a e} \mathrm{ha}^{-1}$, respectively, for 20-cm tall plants (Figure 1B, Table 2). Thus, effective rates determined on the basis of shoot biomass reduction were usually similar to those determined on the basis of visual control estimates. 


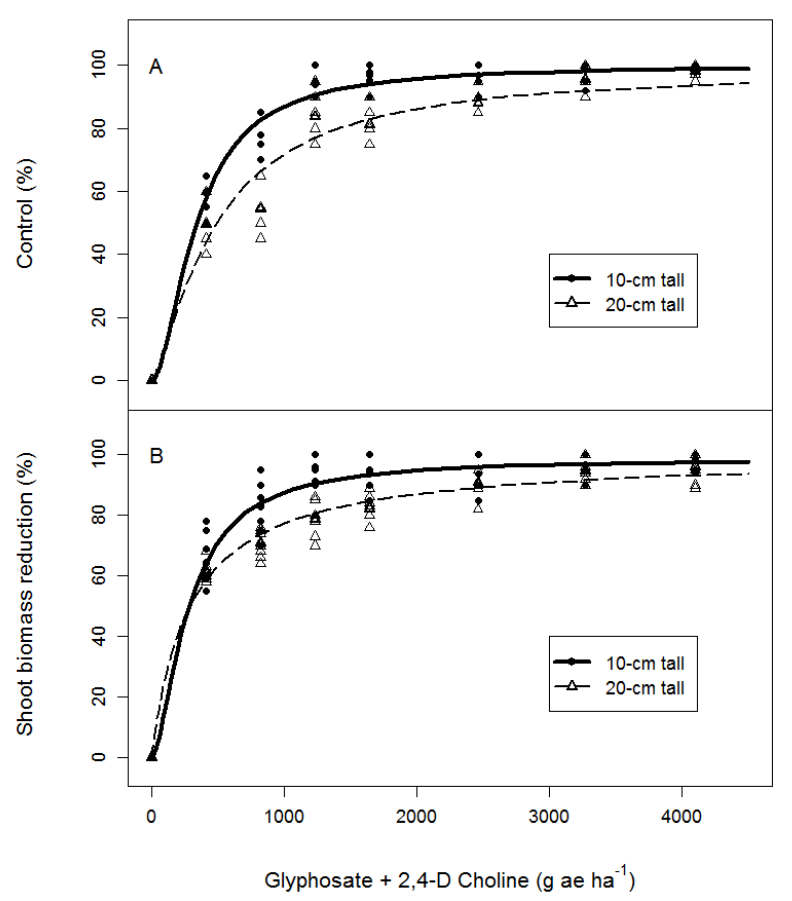

Figure 1. Glyphosate-resistant common waterhemp (A) control of 10- and 20-cm tall plants on the basis of visual injury ratings at $21 \mathrm{~d}$ after treatment (DAT), and (B) percent shoot biomass reduction of 10 - and $20-\mathrm{cm}$ tall plants at 21 DAT in a greenhouse dose response study with a formulation of 2,4-D choline and glyphosate at University of Nebraska-Lincoln

\subsection{Giant Ragweed}

Growth stage of giant ragweed significantly affected herbicide efficacy $(\mathrm{P}<0.0001)$. Dose response curve indicated $\geq 90 \%$ control of 10 -cm tall giant ragweed even with a lower than the recommended rate $(1,640 \mathrm{~g}$ ae $\mathrm{ha}^{-1}$ ) at 21DAT (Figure 2A), while the 20-cm tall giant ragweed was controlled 87 to $93 \%$ at the recommended rate at 21 DAT. Similarly, Vink et al. (2012) reported $>90 \%$ control of 2- to 17-cm tall giant ragweed with 2,4-D ester $\left(500 \mathrm{~g} \mathrm{ae} \mathrm{ha}^{-1}\right)$ applied alone, indicating the sensitivity of giant ragweed to 2,4-D. Higher level of giant ragweed control has been reported in a previous study despite the plant height being higher than recommended. For example, Robinson et al. (2012) reported $\geq 99 \%$ control of 26- to 46-cm tall giant ragweed with 2,4-D (280 g ae $\left.\mathrm{ha}^{-1}\right)$ applied alone or tank-mixed with glyphosate $\left(1,120 \mathrm{~g}\right.$ ae ha $\left.{ }^{-1}\right)$.

The application rates of Enlist Duo ${ }^{\mathrm{TM}}$ required for 50 and $90 \%$ control were 350 and $825 \mathrm{~g} \mathrm{ae} \mathrm{ha}^{-1}$, respectively, for $10-\mathrm{cm}$ tall plants compared to 324 and $1,101 \mathrm{~g} \mathrm{ae} \mathrm{ha}^{-1}$, respectively, for 20-cm tall plants (Figure 2A, Table 1). Similarly, the rates required for 50 and $90 \%$ shoot biomass reduction in $10-\mathrm{cm}$ tall plants were 201 and $805 \mathrm{~g}$ ae $\mathrm{ha}^{-1}$, respectively, compared to 281 and $1142 \mathrm{~g} \mathrm{e} \mathrm{ha}^{-1}$, respectively, for 20-cm tall plants (Figure 2B, Table 2). Results of this study suggested that Enlist Duo ${ }^{\mathrm{TM}}$ herbicide is very effective for controlling glyphosate-resistant giant ragweed. This might be due to giant ragweed's sensitivity to phenoxy herbicides (Robinson et al., 2012; Vink et al., 2012). Recently, Kaur et al. (2014) and Jhala et al. (2014a) reported 99\% control of glyphosate-resistant giant ragweed in Nebraska with herbicide programs that included preplant application of 2,4-D in soybean. 


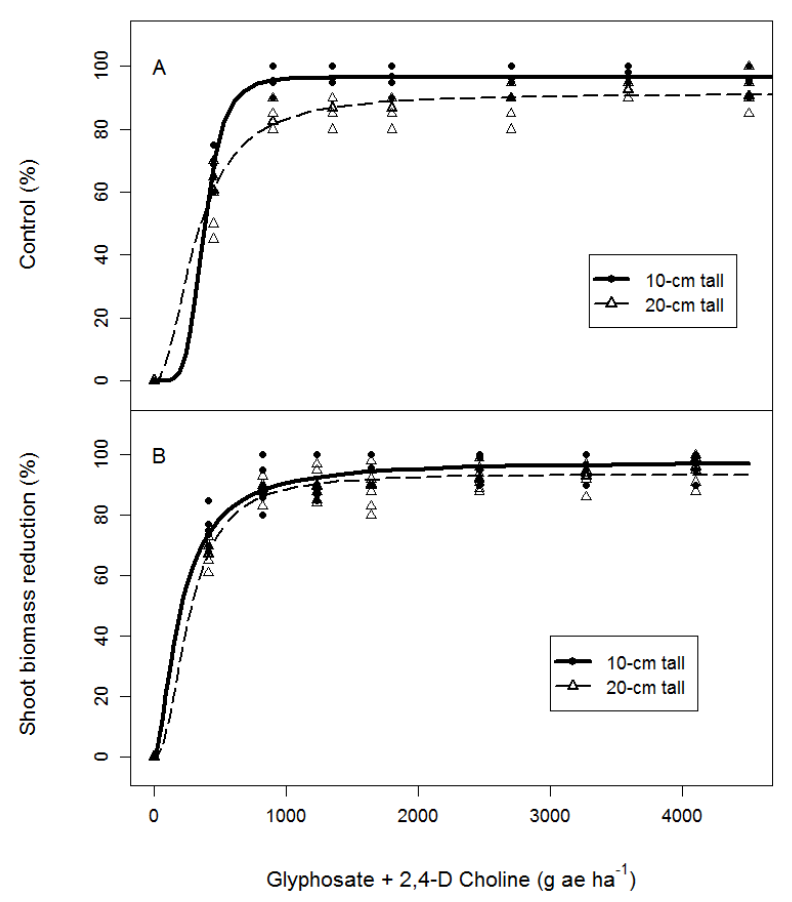

Figure 2. Glyphosate-resistant giant ragweed (A) control of 10- and 20-cm tall plants on the basis of visual injury ratings at $21 \mathrm{~d}$ after treatment (DAT), and (B) percent shoot biomass reduction of 10- and 20-cm tall plants at 21 DAT in a greenhouse dose response study with a formulation of 2,4-D choline and glyphosate at University of

Nebraska-Lincoln

\subsection{Kochia}

Similar to common waterhemp and giant ragweed, visual control and percent shoot biomass reduction of glyphosate-resistant kochia were significantly affected by the growth stage $(\mathrm{P}<0.0001)$. At $21 \mathrm{DAT}, 10-$ and $20-\mathrm{cm}$ tall kochia were controlled 59 to $87 \%$ and 43 to $66 \%$, respectively, at the recommended rate (Figure $3 \mathrm{~A}$ ). Regardless of growth stage and application rate, $\geq 90 \%$ control was not achieved.

Although the shoot biomass curve indicated $90 \%$ reduction at 3,704 $\mathrm{g}$ ae ha ${ }^{-1}$ for $10-\mathrm{cm}$ tall kochia (Figure 3C), the $\mathrm{ED}_{90}$ value for visual control estimates has a limited biological meaning because $90 \%$ control was never achieved regardless of growth stage (Figure 3A, Table 2). Results indicate that the recommended rate of Enlist Duo ${ }^{\mathrm{TM}}$ can provide up to $87 \%$ control of 10 -cm tall kochia, but is less effective for controlling 20 -cm tall plants. Wicks et al. (1994) also reported $75 \%$ control of 2 - to 10 -cm tall glyphosate susceptible kochia and $29 \%$ control of 10- to 20-cm tall plants with 2,4-D ester applied alone. Kochia leaves are pubescent and also have crystalline epicuticular wax which may play an important role in reducing retention and absorption of 2,4-D (Harbour et al. 2003). 


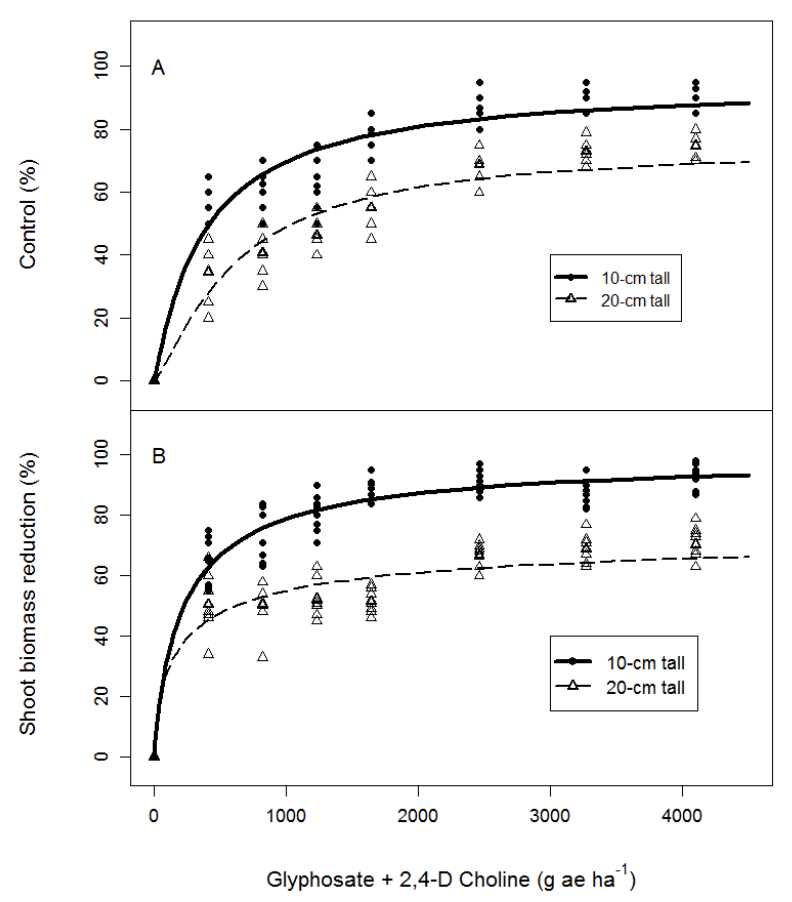

Figure 3. Glyphosate-resistant kochia (A) control of 10- and 20-cm tall plants on the basis of visual injury ratings at $21 \mathrm{~d}$ after treatment (DAT), and (B) percent shoot biomass reduction of 10- and 20-cm tall plants at 21 DAT in a greenhouse dose response study with a formulation of 2,4-D choline and glyphosate at University of Nebraska-Lincoln

\section{Conclusions}

This greenhouse study showed that Enlist Duo ${ }^{\mathrm{TM}}$ is effective for controlling glyphosate-resistant common waterhemp and giant ragweed; however, the effective rates $\left(\mathrm{ED}_{90}\right)$ varied with the weed species and growth stage. Glyphosate-resistant giant ragweed was the most sensitive, with $\geq 90 \%$ control achieved regardless of growth stage, while $10-\mathrm{cm}$ tall glyphosate-resistant common waterhemp was controlled by the recommended rate, though higher rates $\left(\geq 2,480 \mathrm{~g}\right.$ ae ha $\left.{ }^{-1}\right)$ were required to control $20-\mathrm{cm}$ tall plants. Of the three glyphosate-resistant broadleaf weeds studied, kochia was the least sensitive as $90 \%$ control was not achieved regardless of growth stage. Herbicide labels report optimal efficacy at a specific growth stage for different weed species, and several studies have reported reduced efficacy of POST herbicides as weed size increases (Everitt \& Keeling, 2007; Robinson et al., 2012).

Managing glyphosate-resistant weeds is a serious concern for profitable crop production in few countries, including Canada and United States. Additionally, with the evolution of multiple-herbicide-resistant weeds, such as common waterhemp (Bell et al., 2013; Sarangi et al., 2014), kochia (Beckie et al., 2013), and Palmer amaranth (Jhala et al., 2014b), growers' options for effective POST herbicides have dwindled (Tranel et al., 2011). New multiple herbicide-resistant crop technologies can diversify existing herbicide programs by bringing together conventional herbicide chemistries, some of which, such as 2,4-D, are not labeled for POST application in soybean (Craigmyle et al., 2013a, 2013b). Enlist Duo ${ }^{\mathrm{TM}}$ has the potential to control selected glyphosate-resistant weeds, including common waterhemp and giant ragweed. However, over reliance on any herbicide may result in the evolution of resistant weeds. In fact, common waterhemp resistant to 2,4-D has been confirmed in Nebraska (Bernards et al., 2012). Therefore, to avoid selection pressure of herbicide(s) with the same mode(s) of action, growers should adopt integrated weed management approach that include the use of residual herbicides, tank mixing herbicides with different modes of action, and rotation of herbicide-resistant crop technologies in conjunction with cultural and mechanical weed control methods (Aulakh \& Jhala, 2015; Beckie, 2011; Chahal \& Jhala, 2015; Ganie et al., 2015; Norsworthy et al., 2012). The response of tested weed species in terms of visual control estimates and shoot biomass reduction to different rates of formulation of 2,4-D choline and glyphosate observed in this greenhouse study might be different under field conditions. Therefore, field efficacy trials are required to determine the effect of spray parameters and environmental conditions on efficacy of this herbicide for control of glyphosate-resistant weeds. 
Table 1. Regression parameters (Equation 2) and formulation of 2,4-D choline and glyphosate (Enlist DuoTM herbicide) doses (g ae/ha) that provided 50 and $90 \%$ weed control $\left[\mathrm{ED}_{50}( \pm \mathrm{SE}), \mathrm{ED}_{90}( \pm \mathrm{SE})\right]$ on the basis of visual injury ratings at 21 days after treatment (DAT) in a greenhouse dose response study at University of Nebraska-Lincoln

\begin{tabular}{|c|c|c|c|c|}
\hline \multirow{3}{*}{$\begin{array}{l}\text { Glyphosate-resistant weed species } \\
\text { Common waterhemp }\end{array}$} & \multirow{2}{*}{\multicolumn{2}{|c|}{ Regression parameters $( \pm \mathrm{SE})^{\mathrm{a}}$}} & \multirow{2}{*}{\multicolumn{2}{|c|}{$\mathbf{E D}_{\mathbf{5 0}}( \pm \mathbf{S E})^{\mathbf{a}} \quad \mathbf{E D}_{\mathbf{9 0}}( \pm \mathbf{S E})^{\mathbf{a}}$}} \\
\hline & & & & \\
\hline & B & D & & \\
\hline $10-\mathrm{cm}$ tall & $1.76(0.10)$ & $99(0.88)$ & $339(14)$ & 1179 (59) \\
\hline $20-\mathrm{cm}$ tall & $1.34(0.10)$ & $99(1.12)$ & $484(32)$ & $2480(230)$ \\
\hline \multicolumn{5}{|l|}{ Giant ragweed } \\
\hline $10-\mathrm{cm}$ tall & $5.14(1.65)$ & $97(0.51)$ & $350(18)$ & $825(186)$ \\
\hline $20-\mathrm{cm}$ tall & $2.08(0.36)$ & $91(1.34)$ & $324(19)$ & $1101(197)$ \\
\hline \multicolumn{5}{|l|}{ Kochia } \\
\hline $10-\mathrm{cm}$ tall & $1.04(0.10)$ & $100(1.44)$ & $378(41)$ & $4382(380)^{\mathrm{b}}$ \\
\hline $20-\mathrm{cm}$ tall & $1.28(0.11)$ & $75(1.18)$ & $1122(64)$ & $5305(531)^{\mathrm{b}}$ \\
\hline
\end{tabular}

Note. $\mathrm{ED}_{50}$, effective dose required for $50 \%$ control of glyphosate-resistant weeds; $\mathrm{ED}_{90}$, effective dose required for $90 \%$ control of glyphosate-resistant weeds; SE, standard error. The values in parenthesis are standard errors.

${ }^{a}$ Regression parameters B and D for 3-parameter log-logistic model were obtained using the nonlinear least-squares function of the statistical software R.

${ }^{\mathrm{b}}$ These values have limited biological meaning because $90 \%$ control of kochia, regardless of growth stage, was not achieved even with the highest rate of Enlist Duo ${ }^{\mathrm{TM}}$ used in this study.

Table 2. Regression parameters (Equation 2) and formulation of 2,4-D choline and glyphosate (Enlist Duo ${ }^{\mathrm{TM}}$ herbicide) doses (g ae/ha) that provided 50 and $90 \%$ weed control $\left[\mathrm{ED}_{50}( \pm \mathrm{SE}), \mathrm{ED}_{90}( \pm \mathrm{SE})\right]$ on the basis of shoot biomass reduction at 21 days after treatment (DAT) in a greenhouse dose response study at University of Nebraska-Lincoln

\begin{tabular}{|c|c|c|c|c|}
\hline \multirow{2}{*}{$\begin{array}{l}\text { Glyphosate-resistant weed species } \\
\text { Common waterhemp }\end{array}$} & \multicolumn{2}{|c|}{ Regression parameters $( \pm \mathrm{SE})^{\mathrm{a}}$} & \multirow[t]{2}{*}{$\mathrm{ED}_{50}( \pm \mathrm{SE})^{\mathrm{a}}$} & \multirow[t]{2}{*}{$\begin{array}{l}\operatorname{ED}_{90}( \pm \mathrm{SE})^{\mathrm{a}} \\
\mathrm{ha}^{-1}\end{array}$} \\
\hline & B & $\mathrm{D}$ & & \\
\hline $10-\mathrm{cm}$ tall & $1.60(0.3)$ & 99 (2.17) & 303 (24) & $883(330)$ \\
\hline $20-\mathrm{cm}$ tall & $0.98(0.05)$ & $100(1.13)$ & $388(88)$ & 2668 (205) \\
\hline \multicolumn{5}{|l|}{ Giant ragweed } \\
\hline $10-\mathrm{cm}$ tall & $1.58(0.36)$ & 98 (1.67) & $201(32)$ & 805 (144) \\
\hline $20-\mathrm{cm}$ tall & $2.18(0.42)$ & 94 (1.12) & $281(22)$ & $1142(231)$ \\
\hline \multicolumn{5}{|l|}{ Kochia } \\
\hline $10-\mathrm{cm}$ tall & $0.88(0.08)$ & $100(1.24)$ & 227 (32) & $3704(336)^{b}$ \\
\hline $20-\mathrm{cm}$ tall & $0.66(0.10)$ & $76(1.32)$ & $612(87)$ & $5885(1,275)^{\mathrm{b}}$ \\
\hline
\end{tabular}

Note. $\mathrm{ED}_{50}$, effective dose required for $50 \%$ shoot biomass reduction of glyphosate-resistant weeds; $\mathrm{ED}_{90}$, effective dose required for $90 \%$ shoot biomass reduction of glyphosate-resistant weeds; SE, standard error. The values present in parenthesis are standard errors.

${ }^{a}$ Regression parameters B and D for 3-parameter log-logistic model were obtained using the nonlinear least-squares function of the statistical software $\mathrm{R}$.

${ }^{\mathrm{b}}$ This value has limited biological meaning because $90 \%$ shoot biomass reduction of $20-\mathrm{cm}$ tall kochia was not achieved even with the highest rate of 2,4-D choline plus glyphosate used in this study. 


\section{References}

Aulakh, J. S., \& Jhala, A. J. (2015). Comparison of glufosinate-based herbicide programs for broad spectrum weed control in glufosinate-resistant soybean. Weed Technol. (In Press). http://dx.doi.org/10.1614/WT-D-15-00014.1

Aulakh, J. S., Price, A. J., \& Balkcom, K. S. (2011). Weed management and cotton yield under two row spacings in conventional and conservation tillage systems utilizing conventional, glufosinate-, and glyphosate-based weed management systems. Weed Technol., 25, 542-547. http://dx.doi.org/10.1614/WT-D-10-00124.1

Aulakh, J. S., Price, A. J., Enloe, S. F., Wehtje, G., \& Patterson, M. G. (2013). Integrated Palmer amaranth management in glufosinate-resistant cotton: II. Primary, secondary and conservation tillage. Agron., 3, 28-42. http://dx.doi.org/10.3390/agronomy3010028

Aulakh, J. S., Price, A. J., Enloe, S. F., Wehtje, G., Van Santen, E., \& Patterson, M. (2012). Integrated Palmer amaranth management in glufosinate-resistant cotton: i. soil-inversion, high-residue cover crops and herbicide regimes. Agron., 2, 295-311. http://dx.doi.org/10.3390/agronomy2040295

Beckie, H. J. (2006). Herbicide-resistant weeds: management tactics and practices. Weed Technol., 20, $793-814$. http://dx.doi.org/10.1614/WT-05-084R1.1

Beckie, H. J. (2011). Herbicide-resistant weed management: Focus on glyphosate. Pest Manag. Sci., 67, 1037-1048. http://dx.doi.org/10.1002/ps.2195

Beckie, H. J., Blackshaw, R. E., Low, R., Hall, L. M., Sauder, C. A., Martin, S., ... Shirriff, S. W. (2013). Glyphosate- and acetolactate synthase inhibitor-resistant kochia (Kochia scoparia) in Western Canada. Weed Sci., 61, 310-318. http://dx.doi.org/10.1614/WS-D-12-00140.1

Bell, M. S., Hager, A. G., \& Tranel, P. J. (2013). Multiple resistance to herbicides from four site-of-action groups in waterhemp (Amaranthus tuberculatus). Weed Sci., 61, 460-468. http://dx.doi.org/10.1614/WS-D-12-00166.1

Bernards, M. L., Crespo, R. J., Kruger, G. R., Gaussoin, R., \& Tranel, P. J. (2012). A waterhemp (Amaranthus tuberculatus) population resistant to 2,4-D. Weed Sci., 60, 379-384. http://dx.doi.org/10.1614/WS-D-11-00170.1

Chahal, P. S., \& Jhala, A. J. (2015). Herbicide programs for control of glyphosate-resistant volunteer corn in glufosinate-resistant soybean. Weed Technol. (In Press). http://dx.doi.org/10.1614/WT-D-15-00001.1

Chahal, P. S., Kruger, G., Blanco-Canqui, H., \& Jhala, A. J. (2014). Efficacy of pre-emergence and post-emergence soybean herbicides for control of glufosinate-, glyphosate-, and imidazolinone-resistant volunteer corn. J. Agri. Sci., 6, 131-140. http://dx.doi.org/10.5539/jas.v6n8p131

Cordes, J. C., Johnson, W. G., Scharf, P., \& Smeda, R. J. (2004). Late-emerging common waterhemp (Amaranthus rudis) interference in conventional tillage corn. Weed Technol., 18, 999-1005. http://dx.doi.org/10.1614/WT-03-185R

Craigmyle, B. D., Ellis, J. M., \& Bradley, K. W. (2013a). Influence of herbicide programs on weed management in soybean with resistant to glufosinate and 2,4-D. Weed Technol., 27, 78-84. http://dx.doi.org/10.1614/WT-D-12-00099.1

Craigmyle, B. D., Ellis, J. M., \& Bradley, K. W. (2013b). Influence of weed height and glufosinate and 2,4-D combinations on weed control in soybean with resistance to 2,4-D. Weed Technol., 27, 271-280. http://dx.doi.org/10.1614/WT-D-12-00100.1

Culpepper, A. S., Grey, T. L., Vencill, W. K., Kichler, J. M., Webster, T. M., Brown, S. M., ... Hanna, W. W. (2006). Glyphosate resistant Palmer amaranth (Amaranthus palmeri) confirmed in Georgia. Weed Sci., 54, 620-626. http://dx.doi.org/10.1614/WS-06-001R.1

Culpepper, A. S., Whitaker, J. R., MacRae, A. W., \& York, A. C. (2008). Distribution of glyphosate-resistant Palmer amaranth (Amaranthus palmeri) in Georgia and North Carolina during 2005 and 2006. J. Cotton Sci., 12, 306-310.

Everitt, J. D., \& Keeling, J. W. (2007). Weed control and cotton (Gossypium Hirsutum) response to preplant applications of dicamba, 2,4-D, and diflufenzopyr plus dicamba. Weed Technol., 21, 506-510. http://dx.doi.org/10.1614/WT-06-124.1

Ganie, Z. A., Stratman, G., \& Jhala, A. J. (2015). Response of selected glyphosate-resistant broadleaved weeds to 
premix of fluthiacet-methyl and mesotrione (Solstice ${ }^{\mathrm{TM}}$ ) applied at two growth stages. Canadian J. of Plant Sci., 95, 1-9. http://dx.doi/abs/10.4141/CJPS-2014-429

Green, J. M., Hazel, C. B., Forney, D. R., \& Pugh, L. M. (2008). New multiple-herbicide crop resistance and formulation technology to augment the utility of glyphosate. Pest Manag. Sci., 64, 332-339. http://dx.doi.org/10.1002/ps.1486

Harbour, J. D., Messersmith, C. G., \& Ramsdale, B. K. (2003). Surfactants affect herbicides on Kochia (Kochia scoparia) and Russian thistle (Salsola iberica). Weed Science., 51, 430-434. http://dx.doi.org/10.1614/0043

Heap, I. (2015). The international survey of herbicide resistant weeds: Weeds resistant to EPSP synthase inhibitors. Retrieved May 10, 2015, from http://weedscience.org/Summary/MOA.aspx?MOAID=12

Jhala, A. J. (2015). Herbicide-resistant weeds. In S. Z. Knezevic, A. J. Jhala, R. N. Klein, G. R. Kruger, Z. J. Reicher, R. G. Wilson, ... C. L. Ogg (Eds.), Guide for weed management in Nebraska with insecticide and fungicide information (pp. 18-19). Lincoln, NE: University of Nebraska-Lincoln Extension.

Jhala, A. J., Sandell, L. D., \& Kruger, G. (2014a). Control of glyphosate-resistant giant ragweed (Ambrosia trifida L.) with 2,4-D followed by pre-emergence and post-emergence herbicides in glyphosate-resistant soybean (Glycine $\max$ L.). American J. Plant Sci., 5, 2289-2297. http://dx.doi.org/10.4236/ajps.2014.515243

Jhala, A. J., Sandell, L. D., Rana, N., Kruger, G. R., \& Knezevic, S. Z. (2014b). Confirmation and control of triazine and 4-hydroxyphenylpyruvate dioxygenase-inhibiting herbicide-resistant Palmer amaranth (Amaranthus palmeri) in Nebraska. Weed Technol., 28, 28-38. http://dx.doi.org/10.1614/WT-D-13-00090.1

Johnson, W. G., Owen, M. D. K., Kruger, G. R., Young, B. G., Shaw, D. R., Wilson, R. G., ... Weller, S. C. (2009). U.S. farmer awareness of glyphosate-resistant weeds and resistance management strategies. Weed Technol., 23, 308-312. http://dx.doi.org/10.1614/WT-08-181.1

Kaur, S., Sandell, L. D., Lindquist, J. L., \& Jhala, A. J. (2014). Glyphosate-resistant giant ragweed (Ambrosia trifida) control in glufosinate-resistant soybean. Weed Technol., 28, 569-577. http://dx.doi.org/10.1614/WT-D-14-00009.1

Norsworthy, J. K., Scott, R. C., Smith, K. L., \& Oliver, L. R. (2008). Response of northeastern Arkansas Palmer amaranth (Amaranthus palmeri) accessions to glyphosate. Weed Technol., 22, 408-413. http://dx.doi.org/10.1614/WT-07-172.1

Norsworthy, J. K., Ward, S. M., Shaw, D. R., Llewellyn, R. S., Nichols, R. L., Webster, T. M., ... Barrett, M. (2012). Reducing the risks of herbicide resistance: Best management practices and recommendations. Weed Sci., 60, 31-62. http://dx.doi.org/10.1614/WS-D-11-00155.1

Powles, S. B., Lorraine-Colwill, D. F., Dellow, J. J., \& Preston, C. (1998). Evolved resistance to glyphosate in rigid ryegrass (Lolium rigidum) in Australia. Weed Sci., 46, 604-607.

Price, A. J, Balkcom, K. S., Culpepper, S. A., Kelton, J. A., Nichols, R. L., \& Schomberg, H. (2011). Glyphosate-resistant Palmer amaranth: a threat to conservation agriculture. J. Soil Water Conserv., 66, 265-275. http://dx.doi.org/10.2489/jswc.66.4.265

Price, A. J., Balkcom, K. S., Duzy, L. M., \& Kelton, J. A. (2012). Herbicide and cover crop residue integration for Amaranthus control in conservation agriculture cotton and implications for resistance management. Weed Technol., 26, 490-498. http://dx.doi.org/10.1614/WT-D-11-00127.1

Ritz, C., \& Streibig, J. C. (2005). Bioassay Analysis using R. J. Statist Software, 12, 1-22.

Robinson, A. P., Simpson, D. M., \& Johnson, W. G. (2012). Summer annual weed control with 2,4-D and glyphosate. Weed Technol., 26, 657-660. http://dx.doi.org/10.1614/WT-D-12-00081.1

Sarangi, D., Sandell, L. D., Knezevic, S. Z., Aulakh, J. S., Lindquist, J. L., Irmak, S., \& Jhala, A. J. (2014). Confirmation and control of glyphosate-resistant common waterhemp (Amaranthus rudis) in Nebraska. Weed Technol., 29, 82-92. http://dx.doi.org/10.1614/WT-D-14-00090.1

Seefeldt, S. S., Jensen, J. E., \& Fuerst, E. P. (1995). Log-logistic analysis of herbicide dose-response relationships. Weed Technol., 9, 218-227.

Sosnoskie, L. M., \& Culpepper, A. S. (2014). Glyphosate-resistant Palmer amaranth (Amaranthus palmeri) increases herbicide use, tillage, and hand-weeding in Georgia cotton. Weed Sci., 62, $393-402$. http://dx.doi.org/10.1614/WS-D-13-00077.1 
Spaunhorst, D. J., \& Bradley, K. W. (2013). Influence of dicamba and dicamba plus glyphosate combinations on the control of glyphosate-resistant waterhemp (Amaranthus rudis). Weed Technol., 27, 675-681. http://dx.doi.org/10.1614/WT-D-13-00081.1

Tranel, P. J., Riggins, C. W., Bell, M. S., \& Hager, A, G. (2011). Herbicide resistances in Amaranthus tuberculatus: A call for new options. J. Agric Food Chem., 59, 5808-5812. http://dx.doi.org/10.1021/jf103797n

VanGessel, M. J. (2001). Glyphosate-resistant horseweed from Delaware. Weed Sci., 49, 703-705. http://dx.doi.org/10.1614/0043-1745(2001)049[0703:RPRHFD]2.0.CO;2

Vink, J. P., Soltani, N., Robinson, D. E., Tardif, F. J., Lawton, M. B., \& Sikkema, P. H. (2012). Occurrence and distribution of glyphosate-resistant giant ragweed (Ambrosia trifida L.) in southwestern Ontario. Can. J. Plant Sci., 92, 913-922. http://dx.doi.org/10.4141/cjps2011-249

Wicks, G. A., Martin, A. R., Haack, A. E., \& Mahnken, G. W. (1994). Control of triazine-resistant kochia (Kochia scoparia) in sorghum (Sorghum bicolor). Weed Technol., 8, 748-753.

Wilson, R. G., Miller, S. D., Westra, P., Kniss, A. R., Stahlman, P. W., Wicks, G. W., \& Kachman, S. D. (2007). Glyphosate-induced weed shifts in glyphosate-resistant corn or a rotation of glyphosate-resistant corn, sugarbeet, and spring wheat. Weed Technol., 21, 900-909. http://dx.doi.org/10.1614/WT-06-199.1

Wortman, S. E. (2014). Integrating weed and vegetable crop management with multifunctional air-propelled abrasive grits. Weed Technol., 28, 243-252. http://dx.doi.org/10.1614/WT-D-13-00105.1

\section{Notes}

Note 1. Colex-D, Enlist, Enlist Duo, and EnlistE3 are trademarks of Dow Chemical Company ("Dow") or an affiliated company of Dow.

\section{Copyrights}

Copyright for this article is retained by the author(s), with first publication rights granted to the journal.

This is an open-access article distributed under the terms and conditions of the Creative Commons Attribution license (http://creativecommons.org/licenses/by/3.0/). 